\title{
Habaneros and shwarma
}

\author{
Jewish Mexicans in Israel as a transnational community
}

\section{PAULETTE KERSHENOVICH SCHUSTER}

Food is the cultural expression of society as a marker of class, ethnic, and religious identity. What happens when the location changes? Does food continue to play such an important role or do other cultural nodes take over? Do layers of traditions, adaptation and cultural blends emerge? This seems to be the case with third and fourth generation Mexican Jews who have moved to Israel. Not only have they brought their spiritual and cultural connections from Mexico, their birth country; they have also brought the food experiences of their great-grandparents and grandparents who were themselves immigrants. Jewish Mexicans have transplanted their sense of community to Israel and in doing so they have also brought overlooked cultural interactions and unique food experiences. Are these simply by-products of religious and migration patterns? Or are there other elements that have affected this cultural hybridity?

\section{Introduction}

Food is the cultural expression of society and a marker of class, ethnic, and religious identity. ${ }^{1}$ What happens when the location changes? Does food continue to play such an important role or do other cultural nodes take over? Do layers of traditions, adaptation and cultural blends emerge? This seems to be the case with third and fourth generation Mexican Jews who have moved to Israel. Not only have they brought their spiritual and cultural connections from Mexico, their birth country; they have also brought the food experiences of their great-grandparents and grandparents who were themselves immigrants. Jewish Mexicans have transplanted their sense of community to Israel and in doing so they have also brought overlooked cultural interactions and unique food experiences. Are these simply by-products of religious and migration patterns? Or are there other elements that have affected this cultural hybridity?

1 On food and class see Bourdieu I 984: I69-22 5; Goody I 982: 97-I 54. On food and identity see Anderson 2005: I 24-40, I 54-62, I 86-209; Fischler I 988: 275-93; Montanari I999: I89-I94. 
Jews in Mexico infused the traditional Jewish dishes of their ancestors with typical Mexican ingredients such as: chiles, lime, banana and corn leaves, and local herbs and spices like epazote, cilantro and achiote. How do they recreate these flavours in Israel? Israeli cuisine encompasses dishes from a variety of Jewish ethnic cuisines such as North Africa, Spain and Syria (Sephardic tradition) and Eastern Europe (Ashkenazic tradition) reflecting patterns of immigration and acculturation (Rozin 2006: 52-80). The end result is shwarma (an Israeli/Middle Eastern shredded lamb meat dish) topped with spicy babanero salsa (a Mexican ingredient), shakshuka (Israeli poached eggs cooked in a spicy tomato and hot pepper sauce) with jalapeños (Mexican chile) and matzo balls (a traditional Ashkenazi Jewish food) in pozole (a spicy Mexican soup) eaten on Friday nights for Shabbat (the Jewish day of rest). These culinary concoctions and combinations are just some examples of the food fusion between Israeli local cuisine and the Mexican fare mixed in with Jewish religious traditions, or what I call the 'Mexicanization of Israeli foodways'. In other instances the sacredness of food filters in with Jewish and Mexican folk remedies such as hot chicken soup (Jewish comfort food) with cilantro and lime (Mexican ingredients), washed down with a shot of tequila (Mexican hard liquor) and lemon as a cure for the common cold. This religious relationship functions both as an expression of belief and a religious value, forming a symbolic connection to the ancestral past and modern religious cooking and transnational practices. Graham Harvey (2013) contends that religion is not about belief but about practices, which I will discuss at more length later.

This article explores how Jewish Mexicans have recreated their sense of self in Israel by using food as a bastion of their religious, spiritual and cultural identity. Specifically, this article explores the cooking and consumption patterns of Mexican Jews prior to and post immigration to Israel; the shared food experiences of these immigrants; Mexican, Israeli and Jewish cuisines as separate gastronomic diets; the intersections of Mexican-Jewish and Israeli cuisines and traditions; and the nostalgia and memories evoked by these experiences. Lastly, Jewish Mexicans as a transnational community are briefly discussed in relation to food practices. 


\section{Methodology}

This article draws on qualitative and ethnographic research conducted inside Israel. It is based on participant observation, individual in-depth interviews, a review of the existing literature and field research using charlas culiniarias (culinary chats). ${ }^{2}$

A total of fifty interviews have been conducted as part of a larger research project that was begun in December 20I 2. Interviews were conducted with Jewish Mexican women of different generations, religious and socio-economic backgrounds and in various cities throughout Israel. I have included myself in this study as a participant and as a participant observer. As a participant and as a fellow Jewish immigrant from Mexico, I have also shared some of the same life experiences. As a participant observer, I enjoy a vantage point from which I can gauge multiple cooking practices.

For this specific paper, follow-up interviews and casual conversations were conducted with both Israeli and Jewish Mexican men in order to evaluate other narratives of cooking and consumption patterns. Gauging these narratives from a time perspective (years in Israel), places of residency, ethnic/religious backgrounds (among other factors) provided a poignant insight into individual immigrant stories and a greater historical and contemporary understanding of food fusion and adaptation. Interviews conducted were semi-structured with open-ended questions in Spanish and/or Hebrew.

\section{Background of the Jewish Community in Mexico}

As of 2015, the Mexican Jewish community numbered approximately 40,000 (out of a total Mexican population of I I 9 million) and thus represents a very small minority in the country (INEGI). The contemporary formation of the Mexican Jewish community began to coalesce in the late nineteenth century and the first half of the twentieth century, although its historical roots can be traced to the rediscovery of the Americas (Gojman de Backal 1987, Krause 1970, Sourasky 1965). Most Jews entered Mexico between the I920s and 195 os, although immigration flows began earlier in the Porfiriato. ${ }^{3}$ Three

2 I have borrowed the phrase charlas culiniarias, coined by Meredith E. Abarca (2004: I). Although Abarca's research centres on the life experiences and cooking practices of working-class Mexican women, I think these culinary chats are a useful tool for our own purposes.

3 The era of Porfirio Díaz's government from i 876-i 9 I I is known as the Porfiriato. Aside from a brief interregnum from I 880 to 1884 when Díaz personally appointed 
migratory periods with two major waves can be identified: I876-I9II, I9II34, and I934-50 (Kershenovich Schuster 2012).

In Mexico City, there are four main sub-groups (ethno-religious and cultural groups) in the Jewish community, divided according to their ancestral places of national origin: Ashkenazim (Eastern European Jews), Sephardim (from the Iberian Peninsula, Turkey and the Balkans), and two distinct Syrian Jewish subgroups (one Damascene known as Shamis and the other Aleppan known as Halebis). These sub-groups are divided even further into ten community sectors to which the majority of the Judeo-Mexican population is affiliated. ${ }^{4}$ The Jewish Mexican community is highly organized and centralized. Each community sector provides its members a whole array of services. Generally speaking, the Jewish community in Mexico City is considered traditional. ${ }^{5}$

\section{Israel and the Jewish community}

Israel's current population stands at 8,309,400 (as of January 2015, Israel Central Bureau of Statistics). In 2013, Israel welcomed approximately i6,600 new immigrants. During the period I948-20 2, Israel absorbed 224,350 Latin American immigrants. The newcomers were largely from Argentina $(68,545)$, Brazil (I 4,472), Uruguay ( I I 467), Chile $(6,847)$ and Venezuela $(2,597)$ (Israel Central Bureaus of Statistics).

Directly related to this case study, there were 5,067 immigrants from Mexico. Certainly, it is not a high number but it does offer a modest contribution to the overall picture of Latin American immigration. The migratory flows between

Manuel Gonzálex as his temporary successor. Some scholars put the end of Díaz's regime in I9 Io with the start of the Mexican Revolution (1910-20).

I) Beth Israel Community Center (an English speaking institution, which practices Conservative Judaism); 2) the CDI - Jewish Sport Center (sports, cultural, and social institution, which integrates members from all the other sectors); 3) Monterrey's Community Center (the representative institution of Monterrey's Jewish Community);

(4) North Baja California's Community Center (the representative institution of Tijuana's Jewish Community); 5) Ashkenazi Community (formed by descendants of Eastern Europe immigrants.); 6) Bet El Community (an institution which practices Conservative Judaism); 7) Guadalajara's Community Center (the representative institution of Guadalajara's Jewish Community); 8) Maguén David Community (formed by descendants of immigrants from Aleppo); 9) Alianza Monte Sinaí (formed by descendants of immigrants from Damascus) and ro) Sephardic Community (formed by descendants of immigrants from the Iberian Peninsula, Turkey and the Balkans) (Seligson 1973: 203; Tribuna Israelita's website).

5 For more on the religious spectrum and divisions, see DellaPergola and Lerner I 995, Alduncin and Asociados 2000. 
I 948 and I 969 from Mexico were constantly maintained. The first major rise occurred in I969. I have identified five important peaks: I969-73, I975-78, I 982-4, I 995-6, and 2009-Io (based on information tabulated from the Israel Central Bureau of Statistics). Each of these groupings had different push and pull factors, but the majority were tied to patterns of socio-economic instability and general feelings of insecurity.

The I980s ushered in a large influx of Jews from Mexico to Israel, due to economic changes known collectively as the Tequila Crisis. In the I 980 alone, I,005 people entered the country; 929 immigrants arrived in the I 990 and between 2000 and 2010, 8 I 4 people immigrated. Since 20I2, 258 Mexican immigrants have made Israel their home (Israel Central Bureau of Statistics).

\section{Discussion}

What is Jewish cooking? Do we infuse it with certain Jewish elements such as Kashrut? ${ }^{6}$ Is it the simple act of digesting traditional Jewish dishes? ${ }^{7}$ Does it involve a spiritual connection or a greater Jewish nation/peoplehood? ${ }^{8}$ What does it mean to eat Jewishly? Does what we eat make a difference?

Jewish cooking is a daily expression of religious beliefs, ethnic identification, cultural or family history, or a combination of these components (Kraut I 983: 7 I-83; Marks 20 Iо; Spieler 2002; Roden 200I; Montanari and Sabban 2004).9 Transcending social upheavals and countries, it nonetheless encompasses a plethora of ingredients and tastes that reflect the cultural forms and practices, ethnic markers, and religious elements of many Jewish communities worldwide. This combination of global and local is mirrored in the complex constructions of identity among Jews who embrace local cuisine while preserving traditional foods.

Eating Jewishly in this article is defined as consuming food that has been cultivated and harvested using Jewish ethical values. These values are not only tied to Kashrut but to other factors as well. In her presentation 'There's Kashrut, and then there's "eating Jewishly"' Alden Mulhern (2014) implies that eating

6 Kashrut is a term used to refer to the Jewish dietary laws.

7 The act of eating is defined here as the act of converting food into nutrients that supply the body's organs and cells.

8 Jewish peoplehood was first termed in November 2006 (to my knowledge) by the Diaspora Museum when it established the International School for Jewish Peoplehood Studies.

9 On ethnic cuisines and foodways see Buckser 1999, Fischler 1988, Anderson 2005, Bahloul I995. 
Jewishly occupies a higher spiritual plane than Kashrut. By making this connection, Mulhern has brought to the fore an interesting conundrum: that of whether eating Jewishly is more important than Kashrut, and vice versa. She further explains that Jewish eating explores the intersection of Jewish trading and contemporary food issues as embodied in the organization Shoresh. ${ }^{10}$ Many of the followers of this Jewish food movement, propose that having a vegetarian and vegan lifestyle is a good place to start. For most of my informants, eating kosher (or 'keeping kosher') was more important. However, many also stated that kashrut was not a factor in their diet. Although none of my informants followed the principles of eating Jewishly, some of the Israelis I spoke with did follow a vegetarian and vegan diet, reflecting a nationwide trend. For those of my informants that ate according to kashrut, kashrut was held in high spiritual/religious regard. They elevated their diet, cooking practices, lifestyles and beliefs to a level of sacredness (Sered I 988: I 29-39). Thus, creating a religious relationship between their beliefs, cooking and eating practices. For example, by keeping kosher, everyday mundane food was elevated to something special. Moreover, when traditional holiday dishes were prepared, due to their laborious nature and higher spiritual/religious and symbolic connection to the ancestral past, women often cited feeling more attuned and aware of larger forces that united them to a greater Jewishness and Jewish nation/peoplehood.

In Mexico and Israel, the national diets have taken on a dominant role in the everyday food choices and cooking practices of my informants. The culinary influence of both countries is clear and is manifested in the combination of styles, practices and diets involved. Jewish cooking is well integrated into this scenario.

The traditional and modern Mexican diets are and were based on corn. Prehistoric Indians domesticated corn (Quintana 1993: 9) and used it as a component in ritual, as is evidenced in ancient archaeological and pictographic records (Mazzetto and Moragas Segura 2014). The emphasis on this invaluable foodstuff reflects the Mayan belief that humans were moulded and created from corn. ${ }^{11}$ Corn is used as an ingredient in cooking savoury dishes as well as desserts and in a vast amount of products such as syrups, oil, grits, colourings, glucose, flour, animal feed, and starch.

10 As further elaborated in its food conference of 27 January 20I 2. Shoresh is a not-forprofit Jewish Environmental organization. Founded in Toronto in 2002. Among its programmes, it includes a food conference, the Kavanagh garden, Bela Farm, Kollels, CSA, kids', adults' and seniors' programmes and workshops. For more on Shoresh and its founding principles and programmes, see its website.

11 Prehistoric Indians called corn toconayo 'our meat' (Quintana I 993: 9). 
The most important use of corn is in the form of masa, the dough for making tortillas and their variations, as well as for tamales. ${ }^{12}$ According to ancient techniques, dried corn kernels are cooked with water and limestone or quicklime until the corn kernels are soft. After soaking for one day, the kernels are then skinned and ground (Quintana 1993: 9). This ancient cooking practice or process is known as nixtamalización or nixtamalization and is now mechanized, as is the production of tortillas, ${ }^{13}$ except for in remote villages. It is a process that is almost unknown outside of Mesoamerica (Mexico Sabroso's website).

In addition to corn, other important staples include a variety of chiles, tomatoes (green and red), beans, squash and squash blossoms, and avocados, along with cacao and vanilla. Chiles are an integral part of everyday food and are eaten often in the form of salsas, or else sprinkled over fruit, popcorn, corn or popsicles in the form of a powder known as chile piquin; or they are eaten in the form of candy (or as candy) together with tamarind (sweet and spicy). Mexican cuisine is not uniform and varies according to each state and region.

The modern weekday Israeli diet is based largely on fresh vegetables, fruits, and dairy products (Gur 2008; Ziv 2013; Golden 2005: I 8 I-99; Sirkis 2004). Israeli cuisine also incorporates many foods traditionally eaten in other Middle Eastern and Mediterranean cuisines, such as falafel, bummus, shakshouka, and couscous (steamed semolina served with cooked vegetables and broth) (Raviv 2003; Gvion 2006, 2009). ${ }^{14}$ There is currently a debate on the appropriation over ownership of Israeli/Middle Eastern regional dishes, such as bummus and falafel and who was has the right to claim them as their own (Broussard 2007: 691-728; Abu-Fadil 20I I; Ariel 201 2: 34-42; Ranta and Mendel 20I4: I-24). The main debaters in this contested culinary issue are Israelis, Lebanese, and Palestinians. All assert that the origins of these foodstuffs are rightfully theirs.

Food fusion, a process characteristic of the immigrant experience, refers to the trend of combining foods from more than one culture in the same dish. Some examples of food fusion in Mexico include stuffed zucchinis with tamarind sauce; stuffed vine leaves with lemon sauce; artichoke with kipe (a Syrian

12 A tortilla is a foodstuff generally made with dough from nixtamalized maize. It is flat and circular in shape. Tortillas vary in size and colour. They can also be made from white, yellow, blue or violet and/or red corn. They may be small ( 2 inches in diameter) or large (as wide as ro inches). The former are more popular and are known as tortillas taqueras (for tacos). They can also be made with nopales (cacti), and avocados.

13 A mechanized tortilla factory is called a tortillería.

14 On food in the Middle East, see Heine 2004, Zubaida and Rapper I 994, Roden 1994. For general background on the Middles East and its Jews, see Cleveland 2004, Simon et al. 2003. 
dish) and lamb, combined with various types of chiles and spices (such as cinnamon) and served with flour tortillas; meat rolls with ancho chile sauce; and kipe stuffed with beef, serrano chiles and chile piquin.

Israeli cuisine, like other Middle Eastern cuisines, is based on a few key ingredients such as lamb, chicken, dried beans, aubergine, rice and bulgur wheat, olives, yogurt and salty cheese (South and Jermyn 2006: I22). Thus, Jewish dishes, which largely follow the Middle Eastern cuisine except for the strict separation between dishes containing meat and those containing dairy ingredients (according to kashrut), are alive with flavour and healthful ingredients, emphasizing wholegrains, vegetables, legumes, and olive oil (Dweck and Cohen 2007). The Mizrahi cuisine in Israel reflects the convergence of Jews from Iraq, Syria, Lebanon, Yemen, Iran, Algeria, Morocco, Afghanistan, Bukhara (Uzbekistan), Egypt, the Berber communities, Kurdistan, Eastern Caucasus, and Georgia (Bahloul 1989: 85-95; Leichtman 2001: 247-72). It also shares a number of culinary practices with those of Palestinian Arabs (Shihab 1993; Dabbdoub Nasser 200I; Ranta and Mendel 20I4: I-24). Mizrahi food is often light and fresh, concentrating on salads, stuffed vegetables and vine leaves, olive oil, lentils, fresh and dried fruits, herbs and nuts, and chickpeas. Lamb or ground beef are widely used for Shabbat, holiday, and celebratory meals. Rice is a staple of the Mizrahi diet, as are many varieties of flatbread such as lafah, pita and malawach. There are many intra-group variations and modifications. In addition to the influence of Mizrahi and Middle Eastern cuisines, Israeli foodways also integrate the Ashkenazi Jewish diet largely based on potatoes, beets, brisket, chicken and cabbage in various formats (Bernstein and Carmeli 2004).

Initially, during the period of acculturation, Jewish immigrants continued to eat traditional Jewish food after their arrival in Mexico, but gradually Mexican dishes and foodstuffs entered their cuisine. Over time, members of the second and third generations adopted modern Mexican patterns of eating as well as Mexican foods. Jews now enjoy the culinary diversity of Mexican dishes, adapting them at home to meet the requirements of kosher cooking. Thus, for example, chiles en nogada ${ }^{15}$ traditionally made with poblano chiles filled with picadillo (a mixture usually containing fried ground beef, herbs, fruits and spices or diced potatoes and carrots) topped with a walnut-based cream sauce, called nogada, and pomegranate seeds, giving it the three colours of the Mexican flag: green from the chile, white from the nut sauce and red from the pomegranate.

15 The name comes from the Spanish word for the walnut tree, nogal (Diccionario de la Lengua Española). The walnut variety used to prepare nogada is called nogal de Castilla or Castillan walnut. 
Jews adapt this dish by either substituting a cheese filling instead of the picadillo, by omitting the nogada white sauce or by preparing an alternative white sauce made with coconut cream/milk.

Another example includes tostadas (deep-fried tortillas topped with beans, shredded lettuce, some kind of meat, salsa and grated cotija cheese). ${ }^{16}$ Due to kashrut, Jews either omit the cheese or omit the meat and add the cheese. There are many other popular Mexican foods enjoyed by Jews which include tacos, tamales, quesadillas, chilaquiles, enchiladas, enfrijoladas, entomatadas, sopa de tortilla, flautas and corn-on-the cob with various toppings (Quintana 2003).

In Israel, Middle Eastern Jews continued to use food as a symbol of identity, at first signifying regional ethnicity such as Yemenite, Moroccan, Iraqi and later as part of the formation of Mizrahi identity. Middle Eastern Jews also contributed to the formation of a new national Israeli cuisine which incorporated European and Palestinian foods with the various dishes that non-European immigrants brought with them.

For many years, food preferences among Israelis mirrored political and ethnic separations by adopting the Mizrahi/Ashkenazi divide (Dahan Kalev 200I, Smooha 2008, Khazzoom 2008). However, today, the growing acceptance of culinary diversity means that Israeli Jews are more willing to embrace not only their ancestral ethnic cuisines of origin, but other, newer culinary traditions. In Mexico, eating patterns vary in each Jewish community. The community of Jews from Syria tends to consume its own ethnic cuisine. For example, it is rare that Syrian Jews will eat Ashkenazi food, citing that is disgusting and tasteless; conversely comida árabe (Arabic food, the food of the Syrian Jews) is often eaten by Ashkenazim or Sephardim. Adding this culinary value judgment is indicative not of the different palates, but of cultural distinctions and levels of religiosity. Israelis, by contrast, incorporate various forms of ethnic cuisines and make them their own. All of the Israeli informants described their diet as Israeli, although some of the women reported that they ate only traditional Jewish food on a daily basis.

Weekday food in Israel also consists of a mix of styles; mostly Israeli and traditional Jewish dishes mixed with some international dishes (for instance, sushi, pizza, or dim sum). As in Mexico, traditional family meals are eaten on Shabbat, and are often served in a special dining area used only for Shabbat, holidays, and other festive occasions. In Mexico, typically Jewish food is cooked 
by the respondents with the aid of domestic help. ${ }^{17}$ In contrast to the situation in Mexico, food in the Israeli households was not normally prepared by domestic help. Instead, it was prepared by the female members of the household (mothers, mothers-in-law and daughters).

Food fusion does not occur in Israel as widely as it does in Mexico but this trend seems to be changing. Rather than combine various elements into a new dish, Jewish dishes are often served together with other Middle Eastern foods such as szug (a Yemenite chili pepper sauce or spread), which is often added to falafel, tehina, cut vegetable salad, or bummus and is also spread over fish and eggs or chraime (a spicy Moroccan fish with tomatoes). This type of what I call 'parallel' eating and/or cuisine is common and can be seen in other instances as well. ${ }^{18}$

\section{Boundaries, identity, and control: Mexicans in Israel as transnational community}

Jewish Mexicans in Israel function as a transnational community. Transnationalism refers here to those multiple ties and the interactions linked to people or institutions through frontiers and nation-states (Vertovec 2009: $67-8)$. The wider meaning of transnationalism, within the rubric of globalization, includes certain actions or transnational or transcultural practices. Michael Kearney points out that 'transnationalism implies a diffusion or better said a reordering of distinction of binary cultural, social and epistemology of the modern period'(Kearney i 991: 55).

The transnationalism of Jewish Mexicans assumes diverse expressions. They participated actively in the construction of connections and transcultural practices in order to develop and re-create different ethnic, affective and transcultural ties within globalization. ${ }^{19}$ Social networks on the internet play a fundamental role. This has created a virtual imagined community that has transplanted a little bit of Mexico into Israel. In a way, Mexican soil, plus Jewish roots and then in the new context Israeli soil, have combined to form

17 Although they reported receiving some help from their mothers or mothers-in-law on special occasions.

18 I define 'parallel eating' as eating types of foodstuffs in parallel form such as meat, tortillas and chicken, but not together on the same plate. I define 'parallel cuisine' as serving various types of national cuisines side-by-side but again not on the same plate. For example, serving an Asian noodle salad as an appetizer, Indian curried chicken with white rice, and halva (Israeli sesame seed candy) as dessert.

19 On globalization and food culture, see Watson and Caldwell 2005, Fischler I999, and Chase 1994 . 
Jewish-Mexican roots. ${ }^{20}$ On these online forums, Mexican Jews of various religious, socio-economic backgrounds and ages, share everything from political views, the best and worst Mexican restaurants in Israel, which stores are selling Mexican products or Israeli version of products, and who has the best recipe for mole (a thick sauce made with cacao, peanut butter and chiles, and other ingredients) among other things. ${ }^{21}$ The fact that these spaces devote any time to food suggests that this online community serves as a strengthening element of memory, and identity and connection to transnational and transcultural practices. ${ }^{22}$ Another transnational practice demonstrated by my interviewees were their trips to Mexico, typically, every two years. Each time they fly to Mexico, they do so with empty suitcases, which come back full of Mexican foods and sweets not available in Israel.

Another term that goes hand in hand with transnationalism is bifocality. Bifocality here refers to those dual practices in which immigrants constantly compare their places of origin with their adoptive homeland. Many immigrants are involved daily in activities and relations that tie them to the experiences of the nearby or the 'here' and to the distant or the 'there' (Geertz 1983: 55-72).

Examples of some cultural manifestations surrounding food that combine a diasporic identity and transculturalism include: monthly social meetings by Jewish Mexican women in the north and centre of the country; annual celebrations commemorating Mexican Independence, either at Mexican restaurants, barbecues in parks or at various residences of Mexicans and coffee and cake time in the homes of Jewish Mexican women on an ad hoc basis. Any excuse to eat and congregate is greatly valued. Food constitutes the bonding element in these gatherings surpassing differences in their generational, religious and socio-economic backgrounds. The sharing of food acts as a congruent element of personal and collective identity and as an expressive activity (Searles 2002). This network of exchange aids in the incorporation and assimilation of newcomers 'making kinship,' which is central to the social reproduction (Carsten I 995). Thus, food serves as an important vehicle in the production of meaning and identity (Searles 2002) and of making a home. As one Orthodox Jewish

20 It is a twist on Shoresh's Jewish environmental programme entitled 'Canadian soil, Jewish roots.' For more on this, see its website.

21 The word mole comes from the Nahuatl word mulli, which means 'sauce or stew' (Diccionario de la Lengua Española). The dish has its origins in the prehispanic period, when elaborate and various ground sauces that with the passage of time were modified and redefined into the modern version.

22 For more on food and memory, see Holtzman 2006: 36I-78; Bardenstein 2002: 35387; Naguib 2006: 35-53. 
woman in her forties told me: 'food and the whole idea of making food together, not just eating it together, has been a tradition in my family and in many others, I believe food is about taking care, sharing and an important part of making a home'. Some of the younger women I interviewed generally share the view of food as an important aspect of family gatherings and festivities but do not necessarily welcome the idea of cooking with other female members, expecially their mothers-in-law. Some expressed the bond that they share with their grandmothers and mothers in making traditional Jewish food for their own families, despite the fact that they are in different countires. However, there is sometimes discord in the types of food being served on these occasions and in everyday fare.

These acts transplant the Mexican context into an Israeli one, forming a conjuncture between Jewish identity and the Mexican one. This Mexicanidad or 'Mexican-ness' acts as an identitarian space that develops and acquires a new form that extends to a cultural Israeli framework. ${ }^{23}$ In Mexico, the immigrants' hybrid identity as Jews was highlighted but in Israel their Mexican identity takes on a central role. In the end, a new hybrid identity of Mexican-Israeli-Jewish and/or Zionist or Mexican Israelis, Israeli Mexicans, Zionists or any combination thereof is created. On the one hand, participants confront the tripartite condition of having inherited their identity by being born in Mexico but lacking full ancestral Mexicanidad and at the same time, remaining Jewish and carrying on their parents' traditions. This group must constantly prove to outsiders that they are indeed worthy of their ethnic and nationalistic characterizations.

As Jorge Duany (2013) pointed out, the re-creation of companies/businesses is a transnational practice and also a form of cultural production. An important example of this is the opening of restaurants representing the owners' place of origin. In the last decade, there has been a proliferation of restaurants that claim to serve Mexican food. According to an internet-based Israeli restaurant guide (Zaprest), there are 36 Mexican restaurants, but a close examination reveals that the majority are not authentic Mexican venues and only offer a semblance of these flavours. The online restaurant list also included catering businesses or businesses offering prepared food for home delivery. Some were kosher, most were not.

23 Mexicanidad here is used to refer to a socially constructed term for describing not just an adherence to Mexico in national terms but a deep connection to and pride in the land as part of an identity and not as a as a proto-nationalistic 'indianist' movement as described by Susanna Rostas (1997). 
On its window-front, one restaurant in English stated: 'Fresh Mexican food', while in Hebrew it read 'Mexican-American food'. To add insult to injury, inside the establishment there were posters advertising specials with misspelled words in Spanish, as well as American inspired themes and decorations.

The majority of these restaurants offer Tex-Mex food; they are followed by restaurants that serve Latin, South American fare or meat accompanied by tortillas. According to some of my Israeli participants, the fact that these restaurants serve tortillas or tortiot as they are known in Hebrew, magically converts them into Mexican. Even though the so-called 'Tortilla Bars' are popular in Israel, the concept does not exist in Mexico. These establishments typically offer a variety of toppings which are then spooned on top of tortillas. However, as one twenty-something Mexican woman told me: 'I went; it was good that you could build your plate of tacos for only 29 shekels, and get your choice of chicken, beef or vegetables. It wasn't bad in order to get rid of the craving a bit, but it is not authentic Mexican. The tortilla was cold and hard.' By contrast, in Mexico tortillas are soft and are served warm in a tortillero. ${ }^{24}$ In Israel, imported wholewheat and plain flour tortillas can be readily found in local supermarkets and various healthfood stores. Corn tortillas can be purchased through catering services or in speciality stores. Tortillas and Mexican food in general are marketed as a healthy, exotic and vegan alternative.

In Israel, the greatest concentration of these restaurants is located in the centre of the country, reflecting settlement patterns of most of the Jewish Mexican immigrants. Currently there are approximately I,ooo registered Mexican families. ${ }^{25}$ Even though there are clusters of Mexicans in various medium-sized cities throughout Israel such as Herzliyah, Tel Aviv, Karmiel, and Kfar Saba, they do not live in enclaves as they occur in Mexico as denominated by Alejandro Portes ( 1987 ). Moreover, the patterns of settlement are tied to economic activity.

On its website, one of these restaurants lists its purpose: 'to serve ethnic Mexican food in which you can taste a variety of dishes from an authentic Mexican kitchen'. In reality, this is not the case. Only a handful of places serve 'truly authentic' Mexican food. Claiming authenticity in food production is a tricky issue. As noted by Abarca, 'the concept of authenticity marks its presence

24 A tortillero can be a plain basket covered with a cloth, an insular pouch made from cloth or a type of basket manufactured from dried fibres from the maize plant known as chiquibuite which is covered with a small embroidered cloth. When not fried or cooked, tortillas are always served warm or hot. 
in multiple settings: media, cookbooks, literature, classrooms discussion, and casual conversations with friends and colleagues.' (Abarca 2004: I).

One restaurant stood out as the best among the restaurants according to the Jewish Mexicans I spoke with. This establishment was frequented by many of my respondents and used as a meeting place. However, people still complained that it was not too spicy (i.e. not hot enough), that it was expensive and that they do not serve the tortillas warm.

Other restaurants offered parallel cuisines in the same establishment for example: Italian, Spanish and Mexican food; Spanish, American, Mexican and Latin; Cuban, Argentinian, Spanish and Mexican; Italian, American, French and Mexican; Mexican, Japanese and Italian; and Italian, Mexican and Indonesian. These symbolize the many misconceptions Israelis have about what constitutes authentic Mexican food. What they know has been gathered from popular media, travels or from watching the local Israeli soap opera TV channel that features shows mostly from Latin America. As one second-generation Israeli told me: 'I know there are tortiot and that it is very hot street food.'The fact that she thought of it as only street food already points to misinformation and misconstrued perceptions. Israeli fusion culinary inventions include a fastfood place that features a tortilla schnitze ${ }^{26}$ bar, where chicken breast, entrecote, and homemade kebabs (skewers) are all served together with tortillas. Another offered parallel eating by serving meat, tortillas and 'indulgent' foods (dessert). A burger place served 'original churros' (a Mexican fried pastry dessert) filled with Halva (an Israeli sesame seed sweet paste/dessert), nougat and caramel. Again there is misleading information here, since halva and nougat are not used in Mexico. This can be classified as fusion but it is not presented that way.

One Mexican restaurant served 'Mexican brunch' from Io:0o-I 3:00 every Friday and Saturday. This is an interesting occurrence, since the concept of brunch is not really practised in Mexico. What is practised in Mexico is an extended form of breakfast. In other words, people meet for a late breakfast which ends up carrying on into lunch. This is typical among men conducting business meetings or among female socialites gathering with their friends for their weekly meet-up. However, it is not called brunch and it is not an organized event or served in a buffet-style manner as proposed by the label 'brunch' or as practised in the United States.

Not all Mexican restaurants succeed in Israel. One Mexican restaurant in Rishon Lezion (a city in the centre of Israel) closed due to poor service 
and as one Jewish Mexican woman experienced, exceptionally bad food. Not only did the food lack authenticity, but it was also bland. In another instance a Jewish Mexican woman told me: 'There was one near where I lived in Rehovot (another city in cenral Israel). But I didn't go in. It was always empty. Not even flies would stand there, so it didn't appeal to me.'

In lieu of proper Mexican restaurants, many people have opted for growing their own crops (of various chiles such as jalapeños, poblanos and habaneros, green tomatoes or tomatillos and cacti or nopales), and/or cooking and adapting Mexican recipes to local ingredients. As one secular Jewish Mexican thirtytwo-year-old woman, told me: 'I grow real poblano chiles. Made in Israel. I guarantee you that they are great. Not cloned.' This woman grew these chiles for commercial purposes. Over the last five years, many Mexican products have become available in speciality stores, such as mole (red and green), different types of salsas (ranging from mild Tex-Mex style, sweet-spicy mango to hot chipotle salsas), flour for making tortillas, hominy corn, dried chiles (guajillo, cascabel, ancho and pasilla), fresh chiles (poblano, habanero) and pickled nopales to name a few items. Mexican products can also be found in local supermarkets, although the variety is not extensive, such as Mexican-imported juices, tortillas and salsas. In these supermarkets, Israeli-made 'Mexican' products are also available. Such products include Mexican pastrami, organic spicy Mexican peanut butter, Mexican crushed chile and Mexican shata crushed chile, potato chips with 'Mexican' flavour and pita chips with 'spicy Mexican' flavouring. These products to most Mexicans are demeaning and offensive since they constitute stereotypes and misinformation as to what Mexican food is really all about. In the preceding lists there are two interesting examples: Mexican shata crushed chile and the pita chips. The Mexican shata in this case is a misnomer since the shata pepper is an Israeli indigenously-grown pepper unknown in Mexico and the pita chips offer a classic example of food fusion, where a local snack is combined with a foreign product. In this case, the pita snack is the local product and the spicy Mexican component is the foreign element. What is also interesting is the way the words are used: spicy Mexican as in a spicy Mexican person as opposed to using a more appropriate label or presenting them as a Mexican snack instead of fusion. When I asked what made a product 'Mexican', most Israeli people told me that it was 'Mexican' because it was spicy, even though this was not always the case. This lack of awareness leads to cultural and culinary misconceptions. Moreover, in a local supermarket, I found two types of fresh chiles that were labelled as being the same product. They were both labelled as being spicy poblano peppers. One was indeed poblano chiles which are mild to medium-hot, the other was habanero chiles, which are quite hot. This mislabelling shows a lack of knowledge of the product at hand. 
Many Jewish Mexicans have fiddled with and honed their recipes. Some have turned out well, others not so well. For example, one person was able to re-create pozole perfectly by buying hominy corn and boiling it all night and then making the broth with a mixture of dried chiles purchased locally. She then added the accompaniments of shredded lettuce, radishes, diced onions, cubed avocados, wedges of lime and strips of fried tortillas. Traditionally the hominy is boiled with quicklime. Again due to a lack of Mexican products, ingredients or tools, people adapt the recipes and cooking methods. Others were not as successful, as was the case of a person who tried to make barbacoa. Barbacoa in Mexico City is traditionally made from goat meat (cabrito) and is often prepared with parts from the goat's head, such as the cheeks. ${ }^{27}$ Due to kashrut and the lack of available goat meat, this Jewish Ashkenazi male adapted the dish by cutting up beef thinly and frying it, then using store-bought barbecue sauce to simulate the richness of the barbacoa pit. Although quite tasty by his account, it was not authentic. Barbacoa is often served on the banana leaves in which it was cooked, often eaten with onions, diced cilantro and a squeeze of lime juice. Another element that was often substituted by my informants as a side dish was the totopo, which is made of deep-fried, cut up tortillas. The totopos are used as an accompaniment to many dishes or as a tool for dipping. Some informants tried to buy ready-made corn chips or attempted to fry locally bought tortillas. Again, the issue of authenticity came up.

Other informants tried to make elote preparado or prepared corn. The corn cobs are often spread with mayonnaise and sprinkled with lime juice, cotija cheese and chile powder. Off the cob the corn, known as esquites, is sometimes served plain but usually with the same toppings. ${ }^{28}$ Esquites are generally made from fresh corn. They can also be fried and then seasoned with salt. Or they can be sautéed in butter with onions, sprinkled with chile piquin, epazote and salt. Esquites are served hot, in small cups. Since cotija cheese and white corn cannot be found in Israel, yellow sweet corn and parmesan cheese or another hard white cheese have been substituted. In one case, a secular, Jewish Mexican thirty-something man told me he made his own version and called it 'my Israeli corn in the purest Mexican style'. He used mayonnaise, local powdered red pepper flakes and grated tzafit kasha (a hard local Israeli cheese) in his creation. Again, this is an example of immigrants adapting the local ingredients to

27 In northern Mexico, it is sometimes made from the head of a cow and in central Mexico, it is also made with lamb.

28 The word esquites comes from the Nahuatl word izquitl, which means 'toasted corn' (Diccionario de la Lengua Española). 
re-create a comfort food, which reminds them of home. Julie L. Locher et al. (2005) examines the social construction of some food objects as 'comfort foods', highlighting how cultural studies of food should take into account its social and physiological dimensions. Comfort foods are classified into four categories: nostalgic foods, indulgence foods, convenience foods, and physical comfort foods (ibid.). In our case, Jewish Mexicans use three categories of comfort foods: those consumed when feeling nostalgic; as a form of indulgence (when celebrating an event); or for physical reasons (for example when they are sick).

In recreating these dishes, they are trying to symbolize identity within food practices and through the act of consumption. By recreating dishes with local ingredients and within the constraints of kashrut, Jewish Mexicans are actively engaging in a reconstruction of an ideal and identity, a home in limbo. This home is transplanted into the Israeli context. The location and the relationship of foods become key. In doing so, Jewish Mexicans have created a new imagined community (Anderson I 99I) and a community of practice (Wenger I 999) in Israel, one that is infused with the exquisite aromas, tastes, traditions, with nostalgia and memories of home. In her study of Ecuadorian migrants living in New York, Emma-Jayne Abbots (20I I) contends that food from home tastes better than that which they purchase and prepare themselves. As such, the value judgments which are made through this statement, embed taste as culturally and socially influenced. Similarly, in Israel, the shared food experiences of Jewish Mexican immigrants are paramount and serve as catalysts of food practices and human relationships. This culinary exchange between immigrants allows them to proclaim and define their identity through the act of consumption of symbolic food items. As one Mexican Catholic man asked me: 'How do you do it? [How do you] find good Mexican food here?' I answered that I cooked it at home. The he asked me where I bought Mexican products. We discussed and compared opinions regarding the products being offered. And when all else fails in choosing symbolic foods, one can always forego those options as one of my informants eloquently stated: 'I can't stand bummus for lunch. Since I can't eat frijoles [beans] and tortillas, I go get a schnitzel'.

\section{Conclusion}

This article presented an interesting case study of Jewish foodways and the significance of food for Jewish Mexican immigrants in Israel. Food plays a central part in their construction of religious, spiritual and cultural identity, which was constructed in a multiethnic and transnational context through everyday social interactions, cooking and eating practices. These immigrants shared 
experiences and attributes that provided a meaningful social structure and relational narratives.

Specifically, this article explored the cooking and consumption patterns of Mexican Jews before and after immigration to Israel; the shared food experiences of these immigrants; Mexican, Israeli, and Jewish cuisines as separate gastronomic diets; the intersections of Mexican-Jewish and Israeli cuisines and traditions; and the nostalgia and memories they evoke.

It seems that religious, socio-economic backgrounds and generational differences did not affect which type of traditional Jewish food was served in Mexico or in Israel. However, the generation gap was evident in the quantity and frequency of when these dishes were prepared and the style of cooking implemented. The older generation preferred conventional ways of cooking, whereas the younger generation opted for food fusions and parallel eating. Lastly, the concept of Jewish Mexicans as a transnational community was also discussed as it relates to food practices.

\footnotetext{
Paulette Kershenovich Schuster is a Post-Doctoral Fellow at the Hebrew University of Jerusalem. She is the author of a book about women in the Syrian Jewish community in Mexico City. Her work has appeared in numerous publications. A native of Mexico, she was raised both in Mexico City and the United States. She lives in Israel with her husband and four children.
}

\section{References}

\section{Bibliography}

Abarca, Meredith E., 2004. 'Authentic or not, it's original', Food and Foodways: Explorations in the History and Culture of Human Nourishment, I 2(I), pp. I-25

Abbots, Emma-Jayne, 20 I r. 'It doesn't taste as good from the pet shop: guinea pig consumption and the performance of transnational kin and class relations in highland Ecuador and New York City', Food, Culture and Society: An International Journal of Multidisciplinary Research, I4(2), pp. 205-23

Anderson, Benedict, I 991. Imagined Communities: Reflections on the Origin and Spread of Nationalism (London, Verso)

Anderson, Eugene N., 2005. Everyone Eats: Understanding Food and Culture (New York University Press)

Alduncin and Asociados, 2000. Estudio sociodemográfico de la comunidad judía de México Sociodemographic Study of the Jerwish Community in Mexico, a solicitud del Comité Central de la comunidad judía en México (México, Inédito)

Ariel, Ari, 2or 2. 'The hummus wars', Gastronomica: The Journal of Critical Food Studies, I $2(\mathrm{I}), \mathrm{pp} \cdot 34-42$

Bahloul, Joelle, I 989. 'From a Muslim banquet to a Jewish Seder: foodways and ethnicity among North African Jews' in Jerws among Arabs: Contacts and Boundaries, 
ed. Mark Cohen and Abraham Udovitch (Princeton, The Darwin Press), pp. $85-95$

— I 995 . 'Food practices among Sephardic immigrants in contemporary France: dietary laws in urban society', Journal of the American Academy of Religion, 63(3), pp. $485-96$

Bardenstein, Carol, 2002. 'Transmissions interrupted: reconfiguring food, memory and gender in the cookbook-memoirs of Middle Eastern exiles', Signs: Journal of Women in Culture and Society, 28(I), pp. 353-87

Bernstein, Julia, and Yoram S. Carmeli, 2004. 'Food for thought: the dining table and identity construction among Jewish immigrants from the former Soviet Union in Israel' in Consumption and Market Society in Israel, ed. Yoram S. Carmeli and Kalman Applbaum (Berg) (New York, Bloomsbury Academic), pp. 7 I-95

Bourdieu, Pierre, 1984. Distinction: A Social Critique of the Judgment of Taste, trans. Richard Nice (Cambridge, MA, Harvard University Press)

Broussard, J. Austin, 2007. 'An intellectual property food fight: why copyright law should embrace culinary innovation', Vanderbilt Journal. of Entertainment and Tech. Law, I о(3), pp. $69 \mathrm{I}-728$

Buckser, Andrew, I 999. 'Keeping kosher: eating and social identity among the Jews of Denmark', Ethnology, 38(3), pp. I 9 I-209

Carsten, Janet, I 995. 'The substance of kinship and the heat of the hearth: feeding, personhood, and relatedness among Malays in Pulau Langkawi', American Ethnologist, 22(2), pp. 223-4I

Chase, Holly, I 994. 'The Meyhane of McDonald's? Changes in eating habits and the evolution of fast food in Istanbul' in Culinary Cultures of the Middle East, ed. Sami Zubaida and Richard Rapper (London, I.B. Tauris), pp. 63-73

Cleveland, William, 2004. A History of the Modern Middle East (Bunton, Boulder, CO, Westview Press)

Dabbdoub Nasser, Christiane, 200 r. Classic Palestinian Cookery (London, Saqi Books)

Dahan Kalev, Henriette, 200 r. 'Tensions in Israeli feminism: the Mizrahi-Ashkenazi rift', Women's Studies International Forum, 24, pp. I-I6

DellaPergola, Sergio, and Susana Lerner, 1995. La población judia de México. Perfil demográfico, social y cultural (Jerusalem, Hebrew University Press, Avraham Harman Institute of Contemporary Judaism and COLMEX)

Duany, Jorge, 201 3. 'Blurred borders: the Cuban Diaspora in the context of the Hispanic Caribbean', paper presented at the international conference 'Cuba.

Myth and Reality: Culture, History, Politics', Jerusalem, The Hebrew University

Dweck, Poopa, and Michael Cohen, 2007. Aromas of Aleppo: The Legendary Cuisine of Syrian Jerws (New York, Ecco)

Fischler, Claude, I 988. 'Food, self and identity', Social Science Information, 27(2), pp. 275-93

— I 999. 'The McDonaldization of culture' in Food: A Culinary History, ed. Jean-Louis Flandrin, Massimo Montanari, and Albert Sonnenfeld (New York, Columbia University Press), pp. 530-48 
Geertz, Clifford, I 983. Local Knowledge: Further Essays in Interpretative Anthropology

(New York, Basic Books)

Gojman de Backal, Alice, I 987. 'Los conversos en el México Colonial' in Jornadas

Culturales - La presencia judía en México: Memorias (Mexico, UNAM, Tribuna

Israelita y Multibanco Mercantil de México, SNC, México)

Golden, Deborah, 2005. 'Nourishing the nation: the uses of food in an Israeli kindergarten', Food and Foodways, I 3 (3), pp. I 8 I-99

Goody, Jack, I 982. Cooking, Cuisine and Class: A Study in Comparative Sociology

(Cambridge University Press)

Gur, Janna, 2008. The Book of New Israeli Food (Tel Aviv, Al Hashulchan)

Gvion, Liora, 2006. 'Cuisines of poverty as means of empowerment: Arab food in Israel', Agriculture and Human Values, 23(3), pp. 299-3 I 2

2009. 'Narrating modernity and tradition: the case of Palestinian food in Israel', Identities, I6(4), pp. 39 I-4I 3

Harvey, Graham, 2013. Food, Sex and Strangers: Understanding Religion as Everyday Life (Durham, Acumen Publishing)

Heine, Peter, 2004. Food Culture in the Near East, Middle East, and North Africa (Westport, CT, Greenwood Press)

Holtzman, Jon, 2006. 'Food and memory', Annual Review of Anthropology, 35 (I), pp. $36 \mathrm{I}-78$

Kearney, Michael, r99г. 'Borders and boundaries of state and self at the end of empire', Journal of Historical Sociology, 4(I), pp. 52-74

Kershenovich Schuster, Paulette, 20 1 2. The Syrian Jerwish Community in Mexico City in a Comparative Context: Between a Rock and a Hard Place (Germany, LAP Lambert Academic Publishing)

Khazzoom, Aziza, 2008. Shifting Ethnic Boundaries and Inequality in Israel (California, Stanford University Press)

Krause Azen, Corinne, 1970. The Jerws in Mexico: A History with Special Emphasis on the Period from 1857 to 1930, PhD dissertation, University of Pittsburgh

Kraut, Alan, I983. 'The butcher, the baker, the pushcart peddler: Jewish foodways and entrepreneurial opportunity in the East European immigrant community, i 880-i 940', The Journal of American Culture, 6(4), pp. 7 I-83

Leichtman, Mara, 200I. 'The differential construction of ethnicity: the case of Egyptian and Moroccan immigrants in Israel', Identity, I(3), pp. 247-72

Locher, Julie L., William C. Yoels, Donna Maurer, and Jillian van Ells, 2005. 'Comfort foods: an exploratory journey into the social and emotional significance of food', Food and Foodways: Explorations in the History and Culture of Human Nourishment, I3(4), pp. 273-97

Marks, Gil, 20I . Encyclopedia of Jerwish Food (Boston, Houghton Mifflin Harcourt)

Mazzetto, Elena, and Natalia Moragas Segura, 20 r 4. 'Contexts offering and ritual food in the archaeological and pictographic record in central Mexico', paper presented at The Donner Institute's 26th International Research Symposium, 25-27 June 2014 in Åbo/Turku, Finland 
Montanari, Massimo, I 999. 'Food models and cultural identity' in Food: A Culinary History, ed. Jean-Louis Flandrin, Massimo Montanari, and Albert Sonnenfeld (New York, Columbia University Press), pp. I 89-94

Montanari, Massimo, and Françoise Sabban (eds), 2004. Atlante dell'alimentazione e della gastronomia (Torino, UTET)

Mulhern, Aldea, 20 I 4. 'There's kashrut, and then there's “eating Jewishly"', paper presented at The Donner Institute's 26th International Research Symposium, 25-27 June 2014 in Åbo/Turku, Finland

Naguib, Nefissa, 2006. 'The fragile tale of Egyptian Jewish cuisine: food memoirs of Claudia Roden and Colette Rossant', Food and Foodways, I 4(I), pp. 35-53

Portes, Alejandro, I987. 'The social origins of the Cuban enclave economy of Miami', Sociological Perspectives, 30(4), pp. 340-72

Quintana, Patricia, I 993. The Taste of Mexico (New York, Stewart, Tabori and Chang) -2003. El Gran Libro De Los Antojitos Mexicanos (Mexico, Oceano de México)

Ranta, Ronald, and Yonatan Mendel, 20 I4. 'Consuming Palestine: Palestine and Palestinians in Israeli food culture', Ethnicities, I 4(3), pp. 4 I 2-35

Raviv, Yael, 2003. 'Falafel: a national icon', Gastronomica, 3(3), pp. 20-5

Roden, Claudia, I 994. 'Jewish foods in the Middle East' in Culinary Cultures of the Middle East, ed. Sami Zubaida and Richard Rapper (London, I.B. Tauris), pp. $63-73$

200 I. The Book of Jewish Food (New York, Knopf)

Rostas, Susanna, I 997. "Mexicanidad": the resurgence of the Indian in popular Mexican nationalism', paper presented at the Latin American Studies Association, Continental Plaza Hotel, Guadalajara, Mexico

Rozin, Orit, 2006. 'Food, identity, and nation-building in Israel's formative years', Israel Studies Forum, 2 I (I), pp. 52-80

Searles, Edmund, 2002. 'Food and the making of modern Inuit identities', Food and Foodways: Explorations in the History and Culture of Human Nourishment, Io(I-2), pp. 55-78

Seligson Berenfeld, Silvia, I 973. Los judios en México. Un estudio preliminar, BA thesis (Mexico, INAH)

Sered, Susan Starr, I 988. 'Food and holiness: cooking as a sacred act among MiddleEastern Jewish women', Anthropological Quarterly, 6 I (3), pp. I 29-39

Shihab, Aziz, I 993. A Taste of Palestine: Menus and Memories (Texas, Corona Publishing)

Simon, Reeva S., Michael M. Laskier, and Sara Reguer (eds), 2003. The Jerws of the Middle East and North Africa in Modern Times (New York, Columbia University Press)

Sirkis, Ruth, 2004. Popular Food from Israel (Ramat Gan, Israel, R. Sirkis Publishers)

Smooha, Sammy, 2008. 'The mass immigrations to Israel: a comparison of the failure of the Mizrahi immigrants of the I950s with the success of the Russian immigrants of the I990s', The Journal of Israeli History, 27(I), pp. I-27 
Sourasky, León, i 965. Historia de la comunidad israelita de México, 1917-1942 (Mexico, Moderna Pintel)

South, Coleman, and Leslie Jermyn, 2006. Cultures of the World. Syria: Bedrock of Civilizations (New York, Times Editions)

Spieler, Marlena, 2002. The Jewish Heritage Cookbook (London, Anness)

Vertovec, Steven, 2009. Transnationalism (London, Routledge)

Watson, James L., and Melissa L. Caldwell, 2005. 'Food and globalization' in The Cultural Politics of Food and Eating: A Reader, ed. James L. Watson and Melissa L. Caldwell Malden (Hoboken, NJ, Wiley-Blackwell), pp. I-I I

Wenger, Etienne, I 999. Communities of Practice: Learning, Meaning, and Identity (Cambridge University Press)

Ziv, Orly, 201 3. Cook in Israel: Home Cooking Inspiration (Israel, self-published) Zubaida, Sami, and Richard Rapper (eds), I 994. Culinary Cultures of the Middle East (London, I.B. Tauris)

\section{Web sources}

Abu-Fadil, Magda, 20 r r. 'Lebanese TV Spots to Israel: 'Hands Off Our Dishes', HuffPost Media, 25.5.20 I I, <http://www.huffingtonpost.com/magda-abufadil/ lebanese-tv-spots-to-isra_b_I37 I04.html $>$ (accessed I 2.8.20I4)

Diaspora Museum, <http://Bh.org.il/> (accessed 4.7.20I4)

Diccionario de la Lengua Española. Real Academia Española, <http://lema.rae.es/drae/> (accessed I 2.8.2014)

Israel Central Bureaus of Statistics, <http://www.cbs.gov.il/engindex.htm> (accessed 7.8.2014)

Instituto Nacional de Estadística y Geografía - INEGI, <http://www.inegi.org.mx/> (accessed I 2.8.2014)

Mexico Sabroso, el Nixtamal y la tortilla, <http://mexicosabroso.com/20 1 2/03/I 5/elnixtamal-y-la-tortilla/ $>$ (accessed 7.8.2014)

Shoresh, <http://www.shoresh.ca $>$ (accessed 5.8.20I4)

Tribuna Israelita, <http://www.tribuna.org.mx> (accessed 8.5. 2010)

Zaprest: the website for restaurants of Israel, <http://www.rest.co.i1/> (accessed 7.8. 2014) 